(c) American Dairy Science Association, 2004.

\title{
Effects of Feeding Micronized and Extruded Flaxseed on Ruminal Fermentation and Nutrient Utilization by Dairy Cows
}

\author{
C. Gonthier, ${ }^{1}$ A. F. Mustafa, ${ }^{1}$ R. Berthiaume,${ }^{2}$ H. V. Petit, ${ }^{2}$ \\ R. Martineau, ${ }^{2}$ and D. R. Ouellet ${ }^{2}$ \\ ${ }^{1}$ Department of Animal Science, \\ McGill University-Macdonald Campus, \\ Ste-Anne-de-Bellevue, QC H9X 3V9, Canada \\ ${ }^{2}$ Agriculture and Agri-Food Canada, \\ Dairy and Swine Research and Development Centre, \\ Lennoxville, QC J1M 1Z3, Canada
}

\begin{abstract}
Four lactating Holstein cows with ruminal and duodenal cannulas were used in a $4 \times 4$ latin square design to determine the effects of feeding heat-treated flaxseed on ruminal fermentation and site and extent of nutrient utilization. Four diets were formulated: a control diet with no flaxseed, a raw flaxseed diet (RF), a micronized flaxseed diet (MF), and an extruded flaxseed diet (EF). Flaxseed diets contained $12.6 \%$ flaxseed (dry matter $[\mathrm{DM}]$ basis). Ruminal $\mathrm{pH}, \mathrm{NH}_{3} \mathrm{~N}$, and total concentration of volatile fatty acids were not affected by dietary treatments. However, feeding flaxseed decreased the molar proportion of acetate and increased that of propionate. Flaxseed supplementation had no effect on ruminal digestion of $\mathrm{DM}$, organic matter $(\mathrm{OM})$, neutral detergent fiber (NDF), crude protein (CP), fatty acids (FA), and gross energy. However, ruminal digestion of acid detergent fiber (ADF) was lower for cows fed the flaxseed diets than for cows fed the control diet. Feeding flaxseed tended to increase post-ruminal and total tract digestibilities of DM, OM, NDF, and gross energy. Feeding heat-treated flaxseed diets relative to $\mathrm{RF}$ had no effect on ruminal, post-ruminal, and total tract nutrient digestibilities. Cows fed EF had higher ruminal and lower post-ruminal digestibilities of $\mathrm{DM}, \mathrm{OM}, \mathrm{ADF}, \mathrm{CP}$, and FA than cows fed MF. However, total tract digestibilities were similar for the 2 heat treatments. It was concluded that flaxseed supplementation improved total tract nutrient utilization with no adverse effects on ruminal fermentation. Extrusion failed to protect flaxseed from ruminal digestion. However, micronization can be used to increase the ruminal undegraded protein value of flaxseed.
\end{abstract}

Received August 8, 2003.

Accepted January 15, 2004.

Corresponding author: A. F. Mustafa; e-mail: Mustafa@ macdonald.mcgill.ca.
(Key words: flaxseed, ruminal fermentation, nutrient utilization, heat treatment)

Abbreviation key: EF = extruded flaxseed diet, FA = fatty acid, $\mathbf{G E}=$ gross energy, $\mathbf{M F}=$ micronized flaxseed $\operatorname{diet}, \mathbf{R F}=$ raw flaxseed diet.

\section{INTRODUCTION}

Flaxseed (Linum usitatissimum) represents an attractive concentrate for inclusion in lactating dairy cow rations as a source of both energy and protein (Petit, 2002; Mustafa et al., 2003). On a DM basis, flaxseed contains $20 \% \mathrm{CP}, 18 \% \mathrm{NDF}$, and $40 \%$ ether extract (Mustafa et al., 2002). As with other oilseeds, the high level of polyunsaturated fatty acids (FA) in flaxseed can negatively affect ruminal fiber digestion (Palmquist and Jenkins, 1980). Heat treatment can be used to protect oilseeds from ruminal degradation and biohydrogenation by denaturating the protein matrix surrounding the fat droplets (Kennelly, 1996). Heat treatment of different oilseeds, such as flaxseed, soybean, or cottonseed, can alter site of nutrient digestion in the gastrointestinal tract of ruminants (Stern et al., 1985; Pena et al., 1986; Mustafa et al., 2002).

In a previous study, Mustafa et al. (2002) showed that micronization reduces ruminal degradability and increases post-ruminal digestibility of flaxseed in steers. In an in vitro study, Petit et al. (2002) reported similar effects on ruminal DM degradability of flaxseed following micronization at different temperatures. Extrusion is a heat treatment that has the potential to protect oilseeds such as soybeans or cottonseeds from microbial attack in the rumen (Pena et al., 1986; Chouinard et al., 1997a). No in vivo data on the effect of flaxseed and heat-treated flaxseed on nutrient utilization in various segments of the gastrointestinal tract of lactating dairy cows are available. Hence, the objectives of this research were to elucidate the effects of 
feeding ground raw, micronized, and extruded flaxseed on ruminal fermentation, nutrient degradability, and post-ruminal and total tract nutrient digestibilities.

\section{MATERIALS AND METHODS}

\section{Preparation of Flaxseed}

Ground raw and micronized flaxseeds were obtained from InfraReady Products (Saskatoon, SK, Canada). Flaxseed was micronized at $115^{\circ} \mathrm{C}$ for $90 \mathrm{~s}$ using a natural gas-fired micro-red micronizer (Micronizing Company Limited, Suffolk, UK). Extrusion of flaxseed was performed at $155^{\circ} \mathrm{C}$ with a resident time of $43 \mathrm{~s}$ using a multi-purpose twin-screw extrusion system (MPF-50D; Baker Perkins, Food Machinery Division) at Agriculture and Agri-Food Canada (Food Research and Development Centre, St-Hyacinthe, QC).

\section{Animals and Diets}

Four multiparous lactating Holstein cows (BW, 595 $\pm 32 \mathrm{~kg} ; 225 \pm 17$ DIM) fitted with ruminal and duodenal cannulas were used. The cows were kept in tie stalls, bedded on rubber mats with sawdust, with free access to water. Cows were milked twice daily at approximately 0930 and $2100 \mathrm{~h}$.

Dietary treatments consisted of 1) a control diet with no flaxseed added, 2) a raw flaxseed $\operatorname{diet}(\mathbf{R F}), 3)$ a micronized flaxseed diet (MF), and 4) an extruded flaxseed diet (EF). All flaxseed diets consisted of a 55:45 forage:concentrate ratio (DM basis); the control diet had a 64:36 forage:concentrate ratio (DM basis). All diets were formulated to meet nutrient requirements of late lactating dairy cows (NRC, 2001). The forage part of the diets consisted of $60 \%$ grass silage and $40 \%$ corn silage (DM basis). Ingredients and chemical composition of the 4 dietary treatments are shown in Table 1. All diets contained similar levels of CP. However, flaxseed diets contained $8.2 \%$ more NDF and $6.9 \%$ more ADF than did the control diet. Total FA contents were also higher for the flaxseed diets (average, 7.2\%) than for the control diet $(3.5 \%)$.

Diets were fed as TMR for ad libitum intake twice daily at 0830 and $1530 \mathrm{~h}$. Flaxseed was added as topdress for RF, MF, and EF. The amount of flaxseed was adjusted daily for each cow based on the amount of TMR offered so that flaxseed was offered at a constant proportion of the dietary DM $(\sim 12.6 \%)$. The experimental periods $(n=4)$ consisted of $21 \mathrm{~d}$ of diet adaptation and $7 \mathrm{~d}$ of data collection.

Chromic oxide was used as an inert external marker to determine nutrient digestibility and digesta flow. Gelatin capsules containing $8 \mathrm{~g}$ of $\mathrm{Cr}_{2} \mathrm{O}_{3}$ were inserted into the rumen of each cow twice daily starting on $\mathrm{d} 15$ of each period. Diets were sampled twice during each collection week and were composited by period. The composited samples were oven-dried at $55^{\circ} \mathrm{C}$ for $48 \mathrm{~h}$, ground through a 1-mm screen using a Wiley mill (Arthur H. Thomas, Philadelphia, PA), and stored at room temperature for later analysis. Orts were measured every day to determine daily intake for each cow.

\section{Sample Collection and Chemical Analyses}

Samples of ruminal digesta (approximately 11) were collected from various parts of the rumen of each cow on $\mathrm{d} 28$ prior to morning feeding $(0 \mathrm{~h})$ and at $2,4,6,8$, and $12 \mathrm{~h}$. A portion of the whole rumen fluid (approximately $25 \mathrm{~mL}$ ) was squeezed through 4 layers of cheesecloth, and ruminal $\mathrm{pH}$ was determined immediately using a portable $\mathrm{pH}$ meter ( $\mathrm{pH} /$ temp meter 199 Model No 3D; Fisher Scientific, Pittsburgh, PA). Following $\mathrm{pH}$ determination, $5 \mathrm{~mL}$ of filtrate were preserved by adding $1 \mathrm{~mL}$ of sulfuric acid to determine VFA, and 10 $\mathrm{mL}$ of filtrate were preserved by adding $2 \mathrm{~mL}$ of sulfuric acid to determine $\mathrm{NH}_{3} \mathrm{~N}$. Samples were immediately frozen $\left(-20^{\circ} \mathrm{C}\right)$ for later analysis.

Representative samples of ruminal digesta were composited by cow and homogenized for 2 min for isolation of ruminal bacteria using a commercial blender (Waring commercial blender model 33BL73; New Hartford, CT). The composite blended mixture was then squeezed through 2 layers of cheesecloth, mixed with $250 \mathrm{~mL}$ of $\mathrm{NaCl}(0.9 \%)$-formaldehyde (37\%) mixture (1:3 ratio) and then frozen for later bacteria isolation. The bacteria-rich fraction was thawed, and bacteria were isolated using differential centrifugation (Smith and McAllan, 1974). A portion of the bacteria was then oven-dried at $100^{\circ} \mathrm{C}$ overnight to determine $\mathrm{DM}$ content (AOAC, 1990). Total bacterial $\mathrm{N}$ was measured using a Leco Nitrogen Analyzer (FP-428; Nitrogen Determinator System, Leco Corporation, MI). Ruminal bacteria were analyzed for purine content according to the procedure of Zinn and Owens (1986) as modified by Creighton et al. (2000).

Duodenal (400 mL) and fecal (350 g wet basis) samples were collected on d $25(0800,1600,2400 \mathrm{~h})$, d 26 $(1200$ and $2000 \mathrm{~h})$ and $\mathrm{d} 27(0400 \mathrm{~h})$ of each period to represent samples every $4 \mathrm{~h}$ over a 24 -h period. Samples were then stored frozen $\left(-20^{\circ} \mathrm{C}\right)$ for later analysis. Duodenal and fecal samples were later thawed, mixed thoroughly, composited by period and cow, and then refrozen $\left(-20^{\circ} \mathrm{C}\right)$. Duodenal samples were freeze-dried, and fecal samples were dried at $55^{\circ} \mathrm{C}$ for $72 \mathrm{~h}$. Dried samples were ground through a 1-mm screen and stored for later analysis. Duodenal samples were analyzed for purine content as described for ruminal bacteria. 
Table 1. Ingredient (DM basis) and chemical composition (DM basis) of the diets.

\begin{tabular}{|c|c|c|c|c|}
\hline & \multicolumn{4}{|c|}{ Dietary treatment } \\
\hline & Control & $\begin{array}{l}\text { Raw } \\
\text { flaxseed }\end{array}$ & $\begin{array}{l}\text { Micronized } \\
\text { flaxseed }\end{array}$ & $\begin{array}{l}\text { Extruded } \\
\text { flaxseed }\end{array}$ \\
\hline & & 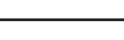 & 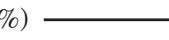 & 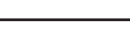 \\
\hline \multicolumn{5}{|l|}{ Ingredient } \\
\hline Grass silage, chopped & 39.9 & 34.8 & 34.7 & 34.7 \\
\hline Corn silage & 23.7 & 20.7 & 20.7 & 20.7 \\
\hline High moisture corn & 26.9 & 23.4 & 23.3 & 23.3 \\
\hline Soybean meal & 6.9 & 6.1 & 6.1 & 6.1 \\
\hline Mineral mix ${ }^{1}$ & 2.3 & 2.1 & 2.1 & 2.1 \\
\hline Limestone & 0.3 & 0.3 & 0.3 & 0.3 \\
\hline Raw flaxseed & - & 12.5 & - & - \\
\hline Micronized flaxseed & - & - & 12.7 & - \\
\hline Extruded flaxseed & - & - & - & 12.7 \\
\hline $\mathrm{DM}$ & 37.2 & 38.4 & 38.4 & 38.5 \\
\hline \multicolumn{5}{|l|}{ Chemical composition } \\
\hline NDF & 39.5 & 42.7 & 43.0 & 42.5 \\
\hline $\mathrm{ADF}$ & 23.1 & 24.7 & 25.0 & 24.5 \\
\hline $\mathrm{ADL}$ & 1.8 & 2.6 & 3.3 & 2.2 \\
\hline $\mathrm{CP}$ & 15.8 & 15.6 & 15.6 & 15.8 \\
\hline Neutral detergent insoluble protein, $\%$ of $\mathrm{CP}$ & 25.0 & 28.7 & 31.1 & 28.3 \\
\hline Acid detergent insoluble protein, $\%$ of $\mathrm{CP}$ & 6.7 & 6.9 & 7.7 & 6.5 \\
\hline Total fatty acids & 3.5 & 7.2 & 7.0 & 7.5 \\
\hline Ash & 7.6 & 7.8 & 7.8 & 7.8 \\
\hline $\mathrm{NE}_{\mathrm{L}},{ }^{2} \mathrm{Mcal} / \mathrm{kg}$ & 1.71 & 1.78 & 1.77 & 1.80 \\
\hline
\end{tabular}

Fecal and duodenal samples were analyzed for DM and total $\mathrm{N}$ as previously described. Neutral detergent fiber and $\mathrm{ADF}$ in fecal and duodenal samples were determined using an Ankom Fiber Analyzer (Ankom Technology Corporation, Fairport, NY). Gross energy (GE) was determined using an oxygen bomb calorimeter (Parr Instrument Company, Moline, IL). Ash was determined by incinerating duodenal and fecal samples in a muffle furnace at $600^{\circ} \mathrm{C}$ for $6 \mathrm{~h}$ (AOAC, 1990). Chromic oxide concentration in duodenal digesta and feces was determined according to the procedure of Fenton and Fenton (1979). Ground feed samples were analyzed for ash, NDF, ADF, GE, and total $\mathrm{N}$ as described for duodenal digesta and fecal samples. Neutral and acid detergent insoluble protein were determined by analyzing $\mathrm{NDF}$ and $\mathrm{ADF}$ residues for total $\mathrm{N}$.

Samples of ruminal fluid preserved for VFA analysis were centrifuged for $15 \mathrm{~min}$ at $10,000 \times \mathrm{g}$ and analyzed for acetic, propionic, butyric, isobutyric, valeric, and isovaleric acids by gas chromatography (Varian model 3400; Varian Canada Inc., Ville St-Laurent, QC, Canada) equipped with a 30 -m capillary column (StabilwaxDA, $0.53 \mathrm{~mm}$ ID; Restek Corporation, Bellefonte, PA). Isocaproic acid was used as the internal standard. Initial column temperature was set at $80^{\circ} \mathrm{C}$ for $30 \mathrm{~s}$ then increased at the rate of $15^{\circ} \mathrm{C} / \mathrm{min}$ until it reached $180^{\circ} \mathrm{C}$.
Temperature was maintained for $1 \mathrm{~min}$; therefore, run time was $8.16 \mathrm{~min}$. Injector and detector temperatures were 250 and $300^{\circ} \mathrm{C}$, respectively. Gas flows were 30, 300 , and $30 \mathrm{~mL} / \mathrm{min}$ for $\mathrm{He}$, air, and $\mathrm{H}_{2}$, respectively. Volume of the sample injected was $0.4 \mu \mathrm{L}$. Ruminal $\mathrm{NH}^{3}$ $\mathrm{N}$ was determined by colorimetry using a multichannel Lachat auto-analyzer (Lachat Instruments, Milwaukee, WI).

Total FA in feed and in fecal and duodenal samples were extracted and methylated by the one-step procedure (Sukhija and Palmquist, 1988) using hexane instead of benzene. Methyl esters of FA were separated and quantified by gas chromatography (Hewlett Packard model 5890 series II, equipped with flame ionization detector at $250^{\circ} \mathrm{C}$ and model 7673 auto injector; Hewlett Packard, Palo Alto, CA) fitted with a fused silica capillary column (SP-2380, $100 \mathrm{~m} \times 0.25 \mathrm{~mm}$; Supelco, Inc., Bellefonte, PA). The carrier gas was $\mathrm{H}_{2}$, and the flow rate was $3.0 \mathrm{~mL} / \mathrm{min}$ (linear flow rate, $34.4 \mathrm{~cm} / \mathrm{s}$ ). Injector and detector temperatures were $250^{\circ} \mathrm{C}$, and the split ratio was 100:1. Column temperature was set at $140^{\circ} \mathrm{C}$ during $1 \mathrm{~min}$ then it increased by $4.0^{\circ} \mathrm{C} / \mathrm{min}$ until it reached $240^{\circ} \mathrm{C}$, where it was maintained for $29 \mathrm{~min}$; therefore, total run time was $55 \mathrm{~min}$. The internal standard used was heptadecanoic acid (C17:0; Nu Check Prep, Inc., Elysian, MN). 


\section{Statistical Analysis}

Data of digestion parameters were subjected to analysis of variance for a Latin square design using the GLM procedure of SAS (1999) with the following model:

$$
\mathrm{Y}_{\mathrm{ijk}}=\mu+\mathrm{T}_{\mathrm{i}}+\mathrm{P}_{\mathrm{j}}+\mathrm{C}_{\mathrm{k}}+\mathrm{e}_{\mathrm{ijk}}
$$

where

$$
\begin{aligned}
\mathrm{Y}_{\mathrm{ijk}}= & \text { observation; } \\
\mu= & \text { population mean; } \\
\mathrm{T}_{\mathrm{i}}= & \text { treatment }(\mathrm{i}=1,2,3, \text { or } 4) ; \\
\mathrm{P}_{\mathrm{j}}= & \text { period }(\mathrm{j}=1,2,3, \text { or } 4) ; \\
\mathrm{C}_{\mathrm{k}}= & \operatorname{random} \text { effect of cow }(\mathrm{k}=1,2,3 \text {, or } 4), \mathrm{C}_{\mathrm{k}} \sim \\
& \mathrm{N}\left(0, \sigma^{2}{ }_{\text {cow }}\right) ; \text { and } \\
\mathrm{e}_{\mathrm{ijk}}= & \text { residual error, } \mathrm{e}_{\mathrm{ijk}} \sim \mathrm{N}\left(0, \sigma^{2}{ }_{\mathrm{e}}\right) .
\end{aligned}
$$

Data of VFA, ruminal $\mathrm{pH}$, and $\mathrm{NH}_{3} \mathrm{~N}$ were analyzed as repeated measurements across time using PROC MIXED of SAS (1999) with the following model:

$$
\mathrm{Y}_{\mathrm{ijkl}}=\mu+\mathrm{T}_{\mathrm{i}}+\mathrm{P}_{\mathrm{j}}+\mathrm{C}_{\mathrm{k}}+\mathrm{S}_{\mathrm{l}}+\mathrm{T}_{\mathrm{i}}^{*} \mathrm{~S}_{\mathrm{l}}+\mathrm{e}_{\mathrm{ijk} \mathrm{l}}
$$

where

$$
\begin{aligned}
\mathrm{Y}_{\mathrm{ijkl}}= & \text { observation; } \\
\mu= & \text { population mean; } \\
\mathrm{T}_{\mathrm{i}}= & \text { treatment }(\mathrm{i}=1,2,3, \text { or } 4) ; \\
\mathrm{P}_{\mathrm{j}}= & \text { period }(\mathrm{j}=1,2,3, \text { or } 4), \\
\mathrm{C}_{\mathrm{k}}= & \text { random effect of cow }(\mathrm{k}=1,2,3, \text { or } 4), \mathrm{C}_{\mathrm{k}} \sim \\
& \mathrm{N}\left(0, \sigma^{2} \text { cow }\right) \\
\mathrm{S}_{1}= & \text { sampling time }(\mathrm{l}=0,2,4,6,8, \text { or } 12 \mathrm{~h}) ; \\
\mathrm{T}_{\mathrm{i}}^{*} \mathrm{~S}_{1}= & \text { treatment by time interaction; and } \\
\mathrm{e}_{\mathrm{ijk}}= & \text { residual error, } \mathrm{e}_{\mathrm{ijkl}} \sim \mathrm{N}(0, \mathrm{R}) . \mathrm{R} \text { is a block diago- } \\
& \text { nal matrix, with } 16 \text { blocks }\left(\mathrm{R}_{\mathrm{ijk}}\right), \text { each } 6 \times 6 \\
& \text { corresponding to the } 6 \text { sampling times, as obser- } \\
& \text { vations from different treatment-period-cow } \\
& \text { were considered to be independent of one an- } \\
& \text { other. }
\end{aligned}
$$

$\mathrm{R}_{\mathrm{ijk}}=\sigma_{\mathrm{e}}^{2} \rho^{\mathrm{S}_{\mathrm{L}}-\mathrm{S}_{\mathrm{L}}{ }^{\prime} \mid}$ a $6 \times 6$ matrix pertaining to the covariances among the repeated sampling measurements. For analysis using the repeated statement of PROC MIXED, a spatial power covariance structure was employed, as the time intervals were not all equal.

All of the fixed effects were tested using the generalized least squares F-test from PROC MIXED (Littell et al., 1996) to account for the repeated measurements on each animal.

Contrasts were control vs. all flaxseed diets, no heat treatment vs. heat treatment, and MF vs. EF. Significance was declared at $P<0.05$.

\section{RESULTS AND DISCUSSION}

\section{Effects of Heat Treatment on Chemical Composition of Flaxseed}

Because all flaxseed treatments were derived from one batch, it was not possible to statistically test differences in chemical composition among treatments. However, it was clear that both heat treatments altered the chemical composition of flaxseed (Table 2). Micronization increased NDF and ADF content of flaxseed by 33 and $44 \%$, respectively. Similarly, neutral and acid detergent insoluble proteins were increased by 59 and $90 \%$, respectively, as a result of micronization. These results are consistent with those previously reported for flaxseed (Mustafa et al., 2002) and soybean (Chouinard et al., 1997b). Changes in chemical composition of flaxseed as a result of extrusion were opposite to those noted for micronization (Table 2). The effects of extrusion on fiber fractions of flaxseed reported in our study agree with other researchers who reported reduction in $\mathrm{NDF}$ and $\mathrm{ADF}$ concentrations of oilseeds as a result of extrusion (Chapoutot and Sauvant, 1997; Petit et al., 1997; Van Dijk et al., 1983). It is possible that extrusion destroyed the protein-fat matrix of flaxseed, thus increasing nutrient solubility (Kennelly, 1996). Reddy et al. (1994) stated that the extrusion process might allow a more rapid release of the seed components into the rumen, a statement which was later supported by Chouinard et al. (2001).

\section{Ruminal Fermentation}

No sampling time $\times$ treatment interactions were observed for ruminal fermentation characteristics; therefore, average values for ruminal $\mathrm{pH}$ and concentrations of $\mathrm{NH}_{3} \mathrm{~N}$ and VFA are presented (Table 3). Average values of ruminal $\mathrm{pH}, \mathrm{NH}_{3} \mathrm{~N}$, and total VFA were not affected by dietary treatments, which is in agreement with other studies where fat supplementation in the form of canola seed (Hussein et al., 1995) or soybeans (Schauff et al., 1992) had no effect on ruminal fermentation characteristics. Madison-Anderson et al. (1997) found that feeding extruded soybeans (17\% of dietary $\mathrm{DM}$ ) had no effect on ruminal $\mathrm{pH}$ or $\mathrm{NH}_{3} \mathrm{~N}$ concentration, but those researchers reported a decrease in total VFA concentration as a result of fat supplementation.

Flaxseed diets decreased and increased, respectively $(P<0.01)$, molar proportions of acetate and propionate, which decreased $(P<0.01)$ the acetate:propionate ratio (Table 3). Because the forage:concentrate ratio was different between the control diet and the flaxseed diets, it is not clear whether differences in molar proportions of acetate and propionate were due to flaxseed supplementation or to differences in forage level. However, 
Table 2. Effects of micronization and extrusion on the chemical composition of flaxseed (DM basis).

\begin{tabular}{lccr}
\hline & \multicolumn{3}{c}{ Flaxseed } \\
\cline { 2 - 4 } & Raw & Micronized & Extruded \\
\hline Ash & 3.7 & 3.7 & 3.3 \\
NDF & 20.2 & 26.9 & 15.3 \\
ADF & 12.4 & 17.9 & 7.8 \\
CP & 22.9 & 22.8 & 22.5 \\
Soluble protein, \% of CP & 33.5 & 26.8 & 42.5 \\
Neutral detergent insoluble protein, \% of CP & 31.5 & 50.1 & 28.0 \\
Acid detergent insoluble protein, \% of CP & 7.0 & 13.3 & 4.5 \\
Total fatty acids & 35.2 & 33.6 & 36.9 \\
Gross energy, Mcal/kg & 6.7 & 6.7 & 6.6 \\
\hline
\end{tabular}

both low forage and high fat levels have been found to have similar effects on molar proportions of VFA (Ferlay et al., 1992; Tesfa, 1993; Khorasani et al., 1996). Lower acetate and greater propionate proportions following addition of oils and oilseeds to ruminant diets are usually related to lower ruminal fiber digestion (Ferlay et al., 1992; Schauff et al., 1992; Tesfa, 1993), which was also the case in our study, where feeding flaxseed diets reduced $(P<0.04)$ ruminal ADF digestibility (expressed as a percentage of $\mathrm{ADF}$ intake) relative to the control diet (Table 4). Isobutyrate was decreased $(P<0.04)$ by flaxseed supplementation (Table $3)$. Molar proportions of butyrate, isobutyrate, and isovalerate in rumen fluid were higher $(P<0.05)$ for cows fed EF than for those fed MF (Table 3). The increase in molar proportions of isoacids noted for EF might have resulted from the greater protein digestibility of extruded relative to micronized flaxseed (Table 5).

\section{Intake, Ruminal, Post-Ruminal, and Total Tract Digestibilities}

Dry matter (average, $15.7 \mathrm{~kg} / \mathrm{d}$ ) and OM (average, $14.4 \mathrm{~kg} / \mathrm{d}$ ) intakes were not affected by flaxseed supple- mentation or by heat treatment (Table 4), suggesting that feeding flaxseed to dairy cows in late lactation up to $12.7 \%$ of dietary DM had no adverse effect on DMI. This is in agreement with other studies, which showed that feeding untreated (Petit, 2002; Ward et al., 2002) or formaldehyde-treated (Petit et al., 2001) flaxseed to dairy cows up to $15 \%$ of dietary DM had no effect on DMI. Similar results have also been reported for other oilseeds (Khorasani et al., 1991; Markus et al., 1996). Addition of fat in the form of oilseeds to ruminant diets usually has less detrimental effects on DMI than if a similar amount is fed as free oil (Kennelly, 1996). In agreement with our data, other studies involving different heat treatments of oilseeds included at different levels up to $17.5 \%$ of dietary DM reported no impact of heat treatments on DMI (Stern et al., 1985; Schingoethe et al., 1996; Chouinard et al., 1997b; Tymchuck et al., 1998).

Flaxseed supplementation had no effect on ruminal digestion (expressed as a percentage of intake) of DM and OM (Table 4). However, the addition of flaxseed increased $(P<0.05)$ post-ruminal digestibility (expressed as a percentage of passage to duodenum) of both DM and OM (Table 4). Total tract DM and OM

Table 3. Ruminal fermentation parameters of dairy cows fed different forms of flaxseed.

\begin{tabular}{|c|c|c|c|c|c|c|c|c|}
\hline & \multicolumn{4}{|c|}{ Dietary treatment } & \multirow[b]{3}{*}{ SEM } & \multirow{2}{*}{\multicolumn{3}{|c|}{ Contrast $^{1}$}} \\
\hline & & Raw & Micronized & Extruded & & & & \\
\hline & Control & flaxseed & flaxseed & flaxseed & & 1 & 2 & 3 \\
\hline $\mathrm{pH}$ & 6.27 & 6.19 & 6.21 & 6.29 & 0.06 & 0.43 & 0.27 & 0.22 \\
\hline $\begin{array}{l}\mathrm{NH}_{3} \mathrm{~N}, \mathrm{mg} / \mathrm{dL} \\
\mathrm{VFA}\end{array}$ & 9.1 & 8.6 & 8.5 & 9.6 & 0.6 & 0.81 & 0.54 & 0.18 \\
\hline $\begin{array}{l}\text { Total, mM } \\
\text { Molar proportion }\end{array}$ & 81.1 & 78.9 & 78.9 & 72.9 & 5.8 & 0.27 & 0.45 & 0.20 \\
\hline Acetate (A) & 65.0 & 62.1 & 62.2 & 61.0 & 0.9 & $<0.01$ & 0.62 & 0.33 \\
\hline Propionate (P) & 20.7 & 24.1 & 24.0 & 24.2 & 0.8 & $<0.01$ & 0.97 & 0.84 \\
\hline Butyrate & 10.4 & 10.1 & 10.3 & 10.8 & 0.2 & 0.94 & 0.09 & 0.05 \\
\hline Isobutyrate & 0.89 & 0.83 & 0.82 & 0.88 & 0.04 & 0.04 & 0.46 & 0.02 \\
\hline Valerate & 1.13 & 1.05 & 1.12 & 1.15 & 0.05 & 0.58 & 0.10 & 0.53 \\
\hline Isovalerate & 1.8 & 1.7 & 1.6 & 1.9 & 0.2 & 0.33 & 0.64 & $<0.01$ \\
\hline A:P & 3.2 & 2.6 & 2.7 & 2.5 & 0.1 & $<0.01$ & 0.97 & 0.51 \\
\hline
\end{tabular}

${ }^{1} 1$ = Control vs. flaxseed, $2=$ raw vs. heat treatments, and $3=$ micronized vs. extruded flaxseed. 
Table 4. Intake, ruminal, post-ruminal, and total tract nutrient digestibilities of dairy cows fed flaxseed diets.

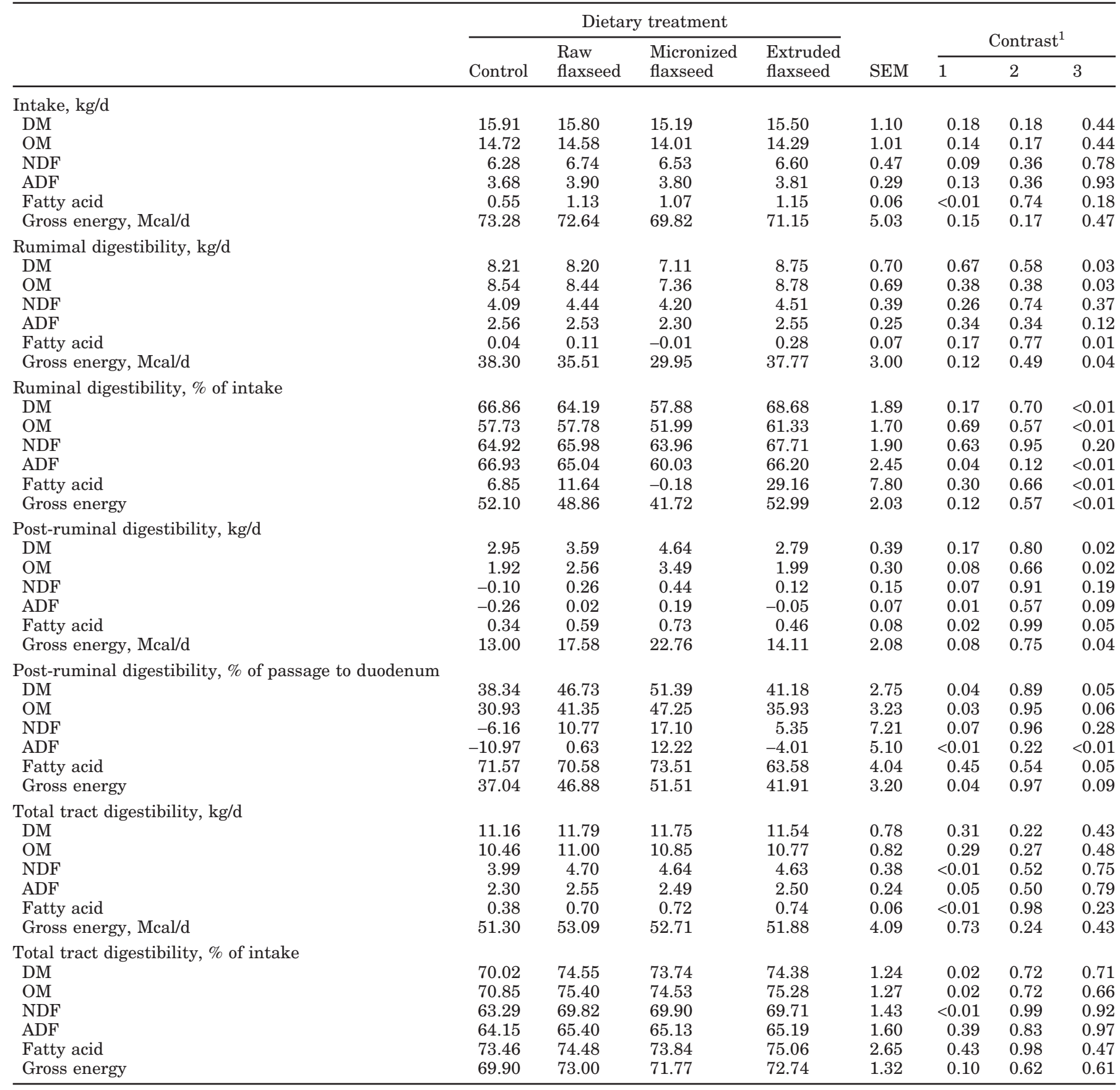

${ }^{1} 1$ = Control vs. flaxseed, 2 = raw vs. heat treatments, and $3=$ micronized vs. extruded flaxseed.

digestibilities (expressed as a percentage of intake) were higher $(P<0.02)$ for cows fed the flaxseed diets than for those fed the control diet. Our results agree with the findings of Orias et al. (2002), which showed an increase in total tract OM digestibility of steers as a result of soybean supplementation.

Cows fed EF had higher $(P<0.01)$ ruminal DM and OM digestibilities (expressed as a percentage of intake), lower $(P<0.05)$ post-ruminal DM, and tended $(P=0.06)$ to have lower post-ruminal OM digestibility (expressed as a percentage of passage to duodenum) than cows fed MF (Table 4). However, total tract digestibilities (expressed as a percentage of intake) of DM and OM were similar for both heat treatments. These results are consistent with a previous study, which showed that micronization reduces ruminal digestibility and 
Table 5. Effects of feeding raw and heated flaxseed on intake and digestibility of CP in various segments of the digestive tract of lactating dairy cows.

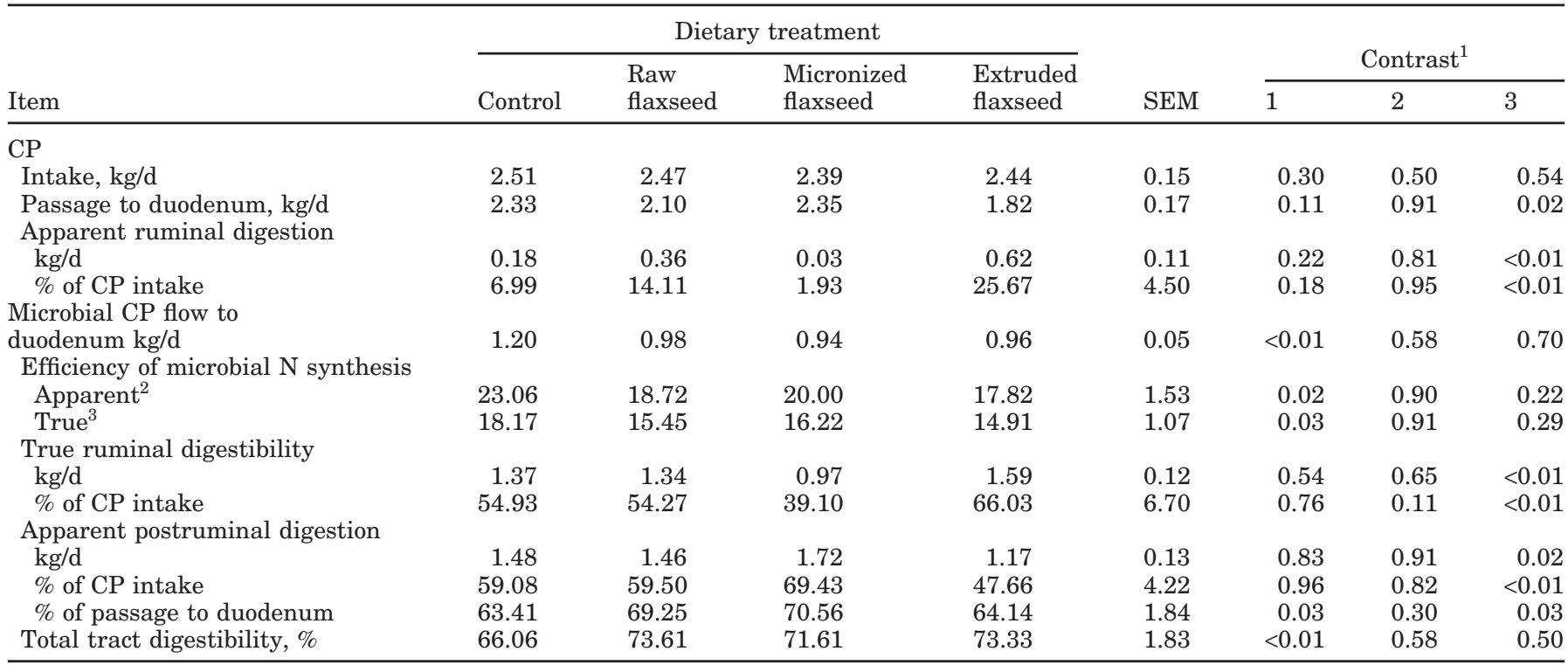

${ }^{1} 1$ = Control vs. flaxseed, 2 = raw vs. heat treatments, and $3=$ micronized vs. extruded flaxseed.

${ }^{2} \mathrm{Grams}$ of microbial N/kg of OM apparently digested in the rumen.

${ }^{3} \mathrm{Grams}$ of microbial N/kg OM truly digested in the rumen.

increases post-ruminal digestibility of flaxseed in steers (Mustafa et al., 2002). The effects of extrusion on ruminal degradability of oilseeds are inconsistent. Several studies have reported a reduction in ruminal degradability of oilseeds as a result of extrusion (Pena et al., 1986; Chouinard et al., 1997a); others showed little effect (Stern et al., 1985; Deacon et al., 1988). Ferlay et al. (1992) suggested that extrusion is less effective than other heat treatments in protecting oilseeds with high fat content from ruminal degradation. Moreover, Melcion et al. (1988) suggested that with high oil content, there is less disruption of the cell structures because of a reduction in shearing forces and heat elevation inside the extruder.

Heat treatment had no effect on ruminal, post-ruminal, and total tract DM and OM digestibilities (Table 4). Despite the fact that it was not possible to contrast the 2 heat treatments individually with $\mathrm{RF}$, it is clear that the effects of EF and MF on ruminal and postruminal digestibilities were opposite relative to $R F$, which may help to explain the lack of differences between heat-treated and raw flaxseed diets.

Intake of ADF was similar among dietary treatments (average, $3.8 \mathrm{~kg} / \mathrm{d})$, and NDF intake tended $(P=0.09)$ to be higher for flaxseed diets compared with the control diet (Table 4). Flaxseed supplementation reduced $(P<$ 0.04 ) ruminal digestion of ADF (expressed as a percentage of $\mathrm{ADF}$ intake), which suggests an inhibition of fibrolytic bacteria. The reduction in ADF digestibility was mainly caused by MF. However, the addition of flaxseed had no effect on ruminal digestion of NDF. Similarly, Tice et al. (1993) found no effect of soybean supplementation (19.7\% of dietary DM) on ruminal digestion of NDF. Ruminal digestibility of ADF was numerically higher than that of NDF for the control diet. This result was likely due to the use of external marker to estimate duodenal flow. Post-ruminal ADF digestibility was higher $(P<0.01)$, and post-ruminal NDF digestibility tended $(P=0.07)$ to be higher, for cows fed the flaxseed diets than for those fed the control diet. Total tract NDF digestibility was higher $(P<0.01)$ for cows fed the flaxseed diets than for cows fed the control diet, whereas total tract ADF digestibility (expressed as a percentage of intake) was not affected by dietary treatments. The improved total tract digestibility of $\mathrm{NDF}$ in the flaxseed diets may be in part due to flaxseed fiber constituents being more digestible than those of the basal diet. In agreement with our results, Aldrich et al. (1995a) reported that soybean supplementation to steers increases total tract NDF digestibility with no effect on ruminal degradation of NDF. Soybean supplementation to dairy cow diets also increases total tract NDF digestibility (Tice et al., 1993).

Ruminal digestion of ADF (expressed as a percentage of intake) was higher $(P<0.01)$ for cows fed EF than for cows fed MF. Post-ruminal ADF digestibility (expressed as a percentage of passage to duodenum) was greater $(P<0.01)$ when MF was fed relative to $\mathrm{EF}$. The 
lack of difference in post-ruminal NDF digestibility may be attributed to the large variation associated with measuring duodenal flow of NDF, which can also explain the negative values observed (Table 4). Total tract $\mathrm{NDF}$ and ADF digestibilities were similar for the 2 heat-treated flaxseed treatments, which would indicate a compensatory effect of the lower gastrointestinal tract when feeding MF to dairy cows compared with EF. Relative to RF, feeding heat-treated flaxseed had no effect on ruminal, post-ruminal, and total tract digestibility of both NDF and ADF. Other studies also showed no effect of feeding heat-treated oilseeds on total tract fiber digestion (Scott et al., 1991, Petit et al., 1997; Shabi et al., 1999).

As expected, FA intake was higher $(P<0.01)$ for cows fed the flaxseed diets (average, $1.1 \mathrm{~kg} / \mathrm{d}$ ) than for cows fed the control diet $(0.55 \mathrm{~kg} / \mathrm{d}$; Table 4$)$. Flaxseed supplementation had no effect on ruminal, post-ruminal, and total tract FA digestibilities when expressed as a percentage of intake or as a percentage of passage to the duodenum. However, when expressed as $\mathrm{kg} / \mathrm{d}$, post-ruminal and total tract FA digestibilities were higher ( $P$ $<0.05$ ) for cows fed flaxseed diets than for those fed the control diet. Ruminal disappearance of FA was higher $(P<0.01)$, and post-ruminal digestion was lower $(P<$ 0.05), for cows fed EF than for those fed MF (Table 4). It is possible that heat and pressure applied during extrusion increased the release of FA into the rumen (Reddy et al., 1994; Chouinard et al., 2001). Total tract FA digestibility was unaffected by heat treatments. Ruminal disappearance and post-ruminal and total tract digestibilities of FA were similar for cows fed diets containing heat-treated flaxseed and those fed RF. In accordance with our findings, Scott et al. (1991) showed that heat treatment of soybeans has no effect on total tract FA digestibility.

Intake of GE was similar among dietary treatments (Table 4). Flaxseed supplementation had no effect on ruminal digestion of GE (Table 4). Flaxseed supplementation increased $(P=0.04)$ post-ruminal digestibility (expressed as a percentage of passage to duodenum) and tended $(P=0.10)$ to increase total tract GE digestibility (expressed as a percentage of intake). Our results are somewhat different from those of Hussein et al. (1995) who found no effect of fat supplementation from crushed canola seed on ruminal or post-ruminal GE digestibilities.

Rumimal digestion of GE (expressed a percentage of GE intake) was lower $(P<0.01)$, and post-ruminal digestion of GE (expressed as a percentage of passage to duodenum), tended to be higher $(P=0.09)$ for cows fed MF than for cows fed EF. If energy at the postruminal level is considered more valuable for dairy cows, then these results suggest that micronization has more potential to increase the feeding value of flaxseed relative to extrusion. Because of the opposite effects of both heat treatments, no differences in ruminal, postruminal, and total tract digestibilities of GE were noted between heat-treated flaxseed diets and RF.

Crude protein intake was similar among dietary treatments (Table 5). Flaxseed reduced $(P<0.05)$ microbial CP flow to the duodenum and microbial efficiencies (true and apparent), which might be an indication that inclusion of flaxseed up to $12.7 \%$ of dietary DM reduced ruminal microbial growth regardless of treatment. Feeding whole soybeans has also been shown to reduce bacterial protein flow to the duodenum (Tice et al., 1993). Reduction in duodenal microbial flow is usually accompanied by a reduction in ruminal fiber digestion (Sauvant and Bas, 2001), which may explain the reduction in ruminal digestion of ADF (expressed as a percentage of intake) noted for cows fed the flaxseed diets (Table 4).

Heat treatment had no effect on duodenal flow of bacterial CP. In accordance with our results, Orias et al. (2002) found no difference in duodenal $\mathrm{N}$ flow when steers were fed raw or extruded soybeans. Aldrich et al. (1995b) reported similar findings when steers were fed raw and roasted soybeans.

Ruminal digestion of CP was not affected by flaxseed supplementation (Table 5). Post-ruminal CP digestibility (percentage of passage to the duodenum) and total tract CP digestibility were greater $(P<0.05)$ for cows fed the flaxseed diets than for those fed the control diet. This result is in agreement with the findings of Orias et al. (2002) who reported higher small intestine protein digestibility for steers fed soybean-supplemented diets than for steers fed a control diet.

Similar to the other nutrients studied, a lower $(P<$ $0.01)$ ruminal and a higher $(P<0.05)$ post-ruminal $\mathrm{CP}$ digestibility were observed for cows fed MF compared with those fed EF (Table 5). Diets containing heattreated flaxseed had similar total tract CP digestibility. Our results are consistent with those of Mustafa et al. (2002) who showed that micronization reduces ruminal and increases post-ruminal CP digestibility of flaxseed without affecting total tract digestibility of $\mathrm{CP}$, which was also shown with canola seeds (Wang et al., 1997). On the contrary, extrusion of flaxseed has been found to increase ruminal $\mathrm{CP}$ digestibility and to reduce the amount of $\mathrm{CP}$ available for digestion post-ruminally (Mustafa et al., accepted). Meyer et al. (2001) also reported an increase in ruminal CP digestibility of cottonseed as a result of extrusion. Heat treatment of oilseeds usually shifts the site of protein digestion from the rumen to the small intestine with little effect on the total tract digestibility (Aldrich et al., 1995b; Wang et al., 1999). However, extrusion has been shown to be less 
effective than other heat treatments in protecting oilseed protein from ruminal degradation (Deacon et al., 1988; Meyer et al., 2001).

Heat treatment had no effect on duodenal flow of bacterial DM, which is in agreement with results of Orias et al. (2002). No differences were observed for ruminal, post-ruminal, and total tract $\mathrm{CP}$ digestibilities between cows fed RF and those fed the heat-treated flaxseed diets (Table 5).

\section{CONCLUSIONS}

Addition of raw or heat-treated flaxseed to dairy cow rations in late lactation up to $12.7 \%$ of dietary DM had no adverse effect on intake, ruminal fermentation, or nutrient utilization. However, a significant reduction in duodenal flow of microbial protein was observed as a result of flaxseed supplementation. Increasing nutrient degradabilities as a result of extrusion did not seem to affect ruminal fiber digestibility of dairy cows. Micronization can be used to increase ruminal undegraded protein content of flaxseed. Further studies are required to study the effects of various heat treatment of flaxseed on milk yield and milk FA composition.

\section{ACKNOWLEDGMENTS}

This study was funded by the Flax Council of Canada, Matching Investment Initiative of Agriculture and Agri-Food Canada, and the Research Partnership Program of the Natural Sciences and Engineering Research Council of Canada. The authors gratefully acknowledge Micheline Pelletier, Sylvie Provencher, Liette Veilleux, and Francois Clavet for assistance in laboratory analysis and the employees of the dairy unit of the Dairy and Swine Research and Development Centre, Lennoxville, QC, Canada, for feeding the cows and assisting with sample collection.

\section{REFERENCES}

Association of Official Analytical Chemists. 1990. Official Methods of Analysis. 15th ed. AOAC, Arlington, VA.

Aldrich, C. G., N. R. Merchen, and J. K Drackley. 1995a. The effects of roasting temperature applied to whole soybeans on site of digestion by steers: I. Organic matter, energy, fiber and fatty acid digestion. J. Anim. Sci. 73:2120-2130.

Aldrich, C. G., N. R. Merchen, D. R. Nelson, and J. A. Barmore. 1995b. The effects of roasting temperature applied to whole soybeans on site of digestion by steers: II Protein and amino acid digestion. J. Anim. Sci. 73:2131-2140.

Chapoutot, P., and D. Sauvant. 1997. Nutritive value of raw and extruded pea-rapeseed blends for ruminants. Anim. Feed Sci. Technol. 65:59-77.

Chouinard, P. Y., L. Corneau, W. R. Butler, Y. Chilliard, J. K. Drackley, and D. E. Bauman. 2001. Effect of dietary lipid source on conjugated linoleic acid concentrations in milk fat. J. Dairy Sci. 84:680-690.
Chouinard, P. Y., V. Girard, and G. J. Brisson. 1997a. Performance and profiles of milk fatty acids of cows fed full fat, heat-treated soybeans using various processing methods. J. Dairy Sci. 80:334-342.

Chouinard, P. Y., J. Levesque, V. Girard, and G. J. Brisson. 1997b. Dietary soybeans extruded at different temperatures: milk composition and in situ fatty acid reactions. J. Dairy Sci. 80:29132924.

Creighton, K. W., R. A. Mass, and T. J. Klopfenstein. 2000. Modifications of the purine assay to increase accuracy and precision. J. Anim. Sci. 78 (Suppl. 1):121.

Deacon, D. A., G. De Boer, and J. J. Kennelly. 1988. Influence of JetSploding and extrusion on ruminal and intestinal disappearance of canola and soybeans. J. Dairy Sci. 71:745-753.

Fenton, T. W., and M. Fenton. 1979. An improved procedure for the determination of chromic oxide in feed and faeces. Can. J. Anim. Sci. 58:631-634.

Ferlay, A., F. Legay, D. Bauchart, C. Poncet, and M. Doreau. 1992. Effect of a supply of raw or extruded rapeseeds on digestion in dairy cows. J. Anim. Sci. 70:915-923.

Hussein, H. S., N. R. Merchen, and G. C. Fahey, Jr. 1995. Effects of forage level and canola seed supplementation on site and extent of digestion of organic matter, carbohydrates, and energy by steers. J. Anim. Sci. 73:2458-2468.

Kennelly, J. J. 1996. The fatty acid composition of milk fat as influenced by feeding oilseeds. Anim. Feed Sci. Technol. 60:137-152.

Khorasani, R. G., E. K. Okine, and J. J. Kennelly. 1996. Forage source alters nutrient supply to the intestine without influencing milk yield. J. Dairy Sci. 79:862-872.

Khorasani, R. G., P. H. Robinson, G. De Boer, and J. J. Kennelly. 1991. Influence of canola fat on yield, fat percentage, fatty acid profile, and nitrogen fractions in Holstein milk. J. Dairy Sci. 74:1904-1911.

Littell, R. C., G. A. Milliken, W. W. Walter, and R. D. Wolfinger. 1996. SAS ${ }^{\circledR}$ System for Mixed Models. SAS Inst., Inc., Cary, NC.

Madison-Anderson, R. J., D. J. Schingoethe, M. J. Brouk, R. J. Baer, and M. R. Lentsch. 1997. Response of lactating cows to supplemental unsaturated fat and niacin. J. Dairy Sci. 80:1329-1338.

Markus, S. B., K. M. Wittenberg, J. R. Ingalls, and M. Undi. 1996. Production responses by early lactation cows to sunflower seed or tallow supplementation of a diet based on barley. J. Dairy Sci. 79:1817-1825.

Melcion, J. P., W. Zernicki, and L. Conan. 1988. L'aliment extrudé colza-pois: une nouvelle matière première. Rev. Aliment. Anim. 417:36-42.

Meyer, M. J., J. E. Shirley, E. C. Tigemeyer, A. F. Park, and M. J. VanBaale. 2001. Effect of mechanical processing and fat removal on the nutritive value of cottonseed for lactating dairy cows. J. Dairy Sci. 84:2503-2514.

Mustafa, A. F., P. Y. Chouinard, and D. A. Christensen. 2003. Effects of feeding micronised flaxseed on yield and composition of milk from Holstein cows. J. Sci. Food Agric. 83:920-926.

Mustafa, A. F., C. Gonthier, and D. R. Ouellet. Effects of extrusion of flaxseed on ruminal and postruminal nutrient digestibilities. Arch. Anim. Nutr. 57:455-463.

Mustafa, A. F., J. J. McKinnon, D. A. Christensen, and T. He. 2002. Effects of micronization of flaxseed on nutrient disappearance in the gastrointestinal tract of steers. Anim. Feed Sci. Technol. 95:123-132.

NRC. 2001. Nutrient Requirements of Dairy Cattle. 7th rev. ed. Natl. Acad. Sci., Washington, DC.

Orias, F., C. G. Aldrich, J. C. Elizalde, L. L. Bauer, and N. R. Merchen. 2002. The effects of dry extrusion temperature of whole soybeans on digestion of protein and amino acids by steers. J. Anim. Sci. 80:2493-2501.

Palmquist, D. L., and T. C. Jenkins. 1980. Fat in lactation rations: review. J. Dairy Sci. 63:1-14.

Pena, F., H. Tagari, and L. D. Satter. 1986. The effect of heat treatment of whole cottonseed on the site and extent of protein digestion in dairy cows. J. Anim. Sci. 62:1423-1433.

Petit, H. V., G. F. Tremblay, E. Tremblay, and P. Nadeau. 2002. Ruminal biohydrogenation of fatty acids, protein degradability, 
and dry matter digestibility of flaxseed treated with different sugar and heat combinations. Can. J. Anim. Sci. 82:241-250.

Petit, H. V. 2002. Digestion, milk production, milk composition, and blood composition of dairy cows fed whole flaxseed. J. Dairy Sci. 85:1482-1490.

Petit H. V., R. J. Dewhurst, J. G. Proulx, M. Khalid, W. Haresign, and $\mathrm{H}$. Twagiramungu. 2001. Milk production, milk composition, and reproductive function of dairy cows fed different fats. Can. J. Anim. Sci. 81:263-271.

Petit, H. V., R. Rioux, and D. R. Ouellet. 1997. Milk production and intake of lactating cows fed raw or extruded peas. J. Dairy Sci. 80:3377-3385.

Reddy, P. V., J. L. Morrill, and T. G. Nagaraja. 1994. Release of free fatty acids from raw or processed soybeans and subsequent effects on fiber digestibilities. J. Dairy Sci. 77:3410-3416.

SAS User's Guide: Statistics, Version 8 Edition. 1999. SAS Inst., Inc., Cary, NC.

Sauvant, D., and P. Bas. 2001. La digestion des lipids chez le ruminant. INRA Prod. Anim. 14:303-310.

Schauff, D. J., J. P. Elliot, J. H. Clark, and J. K. Drackley. 1992. Effects of feeding lactating dairy cows diets containing whole soybeans and tallow. J. Dairy Sci. 75:1923-1935.

Schingoethe, D. J., M. J. Brouk, K. D. Lightfield, and R. J. Baer. 1996. Lactational responses of dairy cows fed unsaturated fat from extruded soybeans or sunflower seeds. J. Dairy Sci. 79:1244-1249.

Scott, T. A., D. K. Combs, and R. R. Grummer. 1991. Effects of roasting, extrusion, and particle size on the feeding value of soybeans for dairy cows. J. Dairy Sci. 74:2555-2562.

Shabi, Z., I. Bruckental, S. Zamwell, H. Tagari, and A. Arieli. 1999. Effects of extrusion of grain and feeding frequency on rumen fermentation, nutrient digestibility, and milk yield and composition in dairy cows. J. Dairy Sci. 82:1252-1260.

Smith, R. H., and A. B. McAllan. 1974. Some factors influencing the chemical composition of mixed rumen bacteria. Br. J. Nutr. $31: 27-34$.
Stern, M. D., K. A. Santos, and L. D. Satter. 1985. Protein degradation in rumen and amino acid absorption in small intestine of lactating dairy cattle fed heat-treated whole soybeans. J. Dairy Sci. 68:45-56.

Sukhija, P. S., and D. L. Palmquist. 1988. Rapid method for determination of total fatty acid content and composition of feedstuffs and feces. J. Agric. Food Chem. 36:1202-1206.

Tesfa, A. T. 1993. Effects of rape-seed oil supplementation on digestion, microbial protein synthesis and duodenal microbial amino acid composition in ruminants. Anim. Feed Sci. Technol. 41:313-328.

Tice, E. M., M. L. Eastridge, and J. L. Firkins. 1993. Raw soybeans and roasted soybeans of different particle sizes. 1. Digestibility and utilization by lactating cows. J. Dairy Sci. 76:224-235.

Tymchuck, S. M., G. R. Khorasani, and J. J. Kennelly. 1998. Effect of feeding formaldehyde- and heat-treated oil seed on milk yield and milk composition. Can. J. Anim. Sci. 78:693-700.

Van Dijk, H. J., G. D. O'Dell, P. R. Perry, and L. W. Grimes. 1983. Extruded versus raw ground soybeans for dairy cows in early lactation. J. Dairy Sci. 66:2521-2525.

Wang, Y., T. A. McAllister, D. R. Zobell, M. D. Pickard, L. M. Rode, Z. Mir, and K.-J. Cheng. 1997. The effect of micronization of fullfat canola seed on digestion in the rumen and total tract of dairy cows. Can. J. Anim. Sci. 77:431-440.

Wang, Y., T. A. McAllister, M. D. Pickard, Z. Xu, L. M. Rode, and K.-J. Cheng. 1999. Effect of micronizing full fat canola seed on amino acid disappearance in the gastrointestinal tract on dairy cows. J. Dairy Sci. 82:537-544.

Ward, A. T., K. M. Wittenberg, and R. Przybylski. 2002. Bovine milk fatty acid profiles produced by feeding diets containing solin, flax and canola. J. Dairy Sci. 85:1191-1196.

Weiss, W. P., H. R. Conrad, and N. R. St. Pierre. 1992. A theoreticallybased model for predicting total digestible nutrient values of forages and concentrates. Anim. Feed Sci. Technol. 39:95-110.

Zinn, R. A., and F. N. Owens. 1986. A rapid procedure for purine measurement and its use for estimating net ruminal protein synthesis. Can. J. Anim. Sci. 66:157-166. 